Tecnología y

Ciencias $\stackrel{\Xi}{\unlhd}$ gua
2022, Instituto Mexicano de Tecnología del Agua Open Access bajo la licencia CC BY-NC-SA 4.0 (https://creativecommons.org/licenses/by-nc$\mathrm{sa} / 4.0 /)$

DOI: $10.24850 / j-t y c a-2022-01-10$

Articles

\title{
Variation of surface runoff due to change of land use in the river Duero watershed
}

\section{Variación de la escorrentía superficial por el cambio de uso de suelo en la cuenca del río Duero}

Nelly Bernal-Santana ${ }^{1}$

Gustavo Cruz-Cárdenas², ORCID: https://orcid.org/0000-0002-52564612

José Teodoro Silva3, ORCID: https://orcid.org/0000-0003-4516-6461

Sergio Martínez-Trinidad4, ORCID: https://orcid.org/0000-0002-98801994

Rodrigo Moncayo-Estrada5, ORCID: https://orcid.org/0000-0003-02041482

Francisco Estrada-Godoy6, ORCID: https://orcid.org/0000-0003-45465656

Salvador Ochoa-Estrada7, ORCID: https://orcid.org/0000-0002-89332882

Dioselina Álvarez-Bernal8, ORCID: https://orcid.org/0000-0002-59467292 
Tecnología y

Ciencias $\stackrel{\Xi}{\Im}$ Aua
2022, Instituto Mexicano de Tecnología del Agua

Open Access bajo la licencia CC BY-NC-SA 4.0 (https://creativecommons.org/licenses/by-nc$\mathrm{sa} / 4.0 /)$

${ }^{1}$ Instituto Politécnico Nacional, CIIDIR-IPN-Michoacán, COFAA, Jiquilpan, Michoacán, Mexico,nlygeo@gmail.com

2Instituto Politécnico Nacional, CIIDIR-IPN-Michoacán, COFAA, Jiquilpan, Michoacán, Mexico, guscruz@ipn.mx, gustavo.cruz.cardenas@gmail.com

3Instituto Politécnico Nacional, CIIDIR-IPN-Michoacán, COFAA, Jiquilpan, Michoacán, Mexico, tsilva09@hotmail.com

${ }^{4}$ Colegio de Postgraduados, Campus Puebla, Puebla, Mexico, sergiomtzt@colpos.mx

5Instituto Politécnico Nacional, CICIMAR, COFAA, Av. Instituto Politécnico Nacional s/n, 23096, La Paz, BCS, México, rmoncayo@hotmail.com

${ }^{6}$ Instituto Politécnico Nacional, Escuela Superior de Ingeniería y Arquitectura (ESIA), Mexico City, Mexico, ingestrada01@hotmail.com

7Instituto Politécnico Nacional, CIIDIR-IPN-Michoacán, COFAA, Michoacán, Mexico, sochoae@ipn.mx

8Instituto Politécnico Nacional, CIIDIR-IPN-Michoacán, COFAA, Michoacán, Mexico, dalvarezb@ipn.mx

Corresponding author: Gustavo Cruz-Cárdenas, guscruz@ipn.mx, gustavo.cruz.cardenas@gmail.com

\section{Abstract}

The dynamics and availability of the water resource is fundamental aspect in the study of watersheds. From the temporal perspective, water 
Tecnología y

Ciencias $\stackrel{\unlhd}{\unlhd}$ gua
2022, Instituto Mexicano de Tecnología del Agua

Open Access bajo la licencia CC BY-NC-SA 4.0

(https://creativecommons.org/licenses/by-ncsa/4.0/)

resource is related to precipitation, which varies with hydrometeorological events, while spatially, it is largely related to the land use or vegetation cover. The changes in surface runoff of the Duero River basin, Mexico, using the SWAT model were investigated. The input data for the model include climatic variables, soil properties, topography, and four periods of land use map. The runoff estimates of the SWAT were compared with the streamflow data from the National Data Bank of Surface Water. An elevated record of runoff of up to $30 \mathrm{Dam}^{3}$ (cubic decameter) was observed in 1983 in the municipalities of Tangamandapio and Tangancicuaro, which was likely associated with forest clearing since the 1970s. A decrease of runoff to $10 \mathrm{Dam}^{3}$ was also observed in 2000, likely reflecting the conservation practice of forest management. The simulations for 2011 and 2014 indicate high runoff in the municipality of Chilchota due to the modification of its forest areas and traditional agriculture to accommodate the cultivation of the avocado crop and berries.

Keywords: SWAT model, artificial neural networks, digital mapping.

\section{Resumen}

La dinámica y disponibilidad del recurso hídrico es un aspecto fundamental en el estudio de las cuencas hidrográficas. Desde la perspectiva temporal, el recurso hídrico está relacionado con la precipitación, que varía con los eventos hidrometeorológicos, mientras que espacialmente, está relacionado en gran medida con el uso de la 


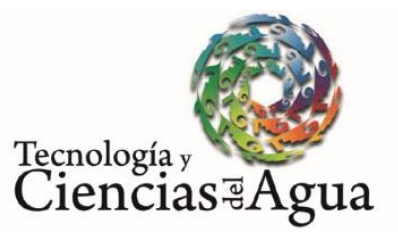
2022, Instituto Mexicano de Tecnología del Agua Open Access bajo la licencia CC BY-NC-SA 4.0 (https://creativecommons.org/licenses/by-nc- $\mathrm{sa} / 4.0 /$ )

tierra o la cubierta vegetal. Se investigaron los cambios en la escorrentía superficial del río Duero basin, México, utilizando el modelo SWAT. The input data for the model include climatic variables, soil properties, topography, and four periods of land use map. Las estimaciones de escorrentía del SWAT se compararon con los datos de caudal del Banco Nacional de Datos de Aguas Superficiales. En 1983 se observó un registro elevado de escorrentía de hasta $30 \mathrm{Dam}^{3}$ (decámetro cúbico) en los municipios de Tangamandapio y Tangancícuaro, que probablemente se asoció con la tala de bosques desde la década de 1970; también se observó una disminución de escorrentía a $10 \mathrm{Dam}^{3}$ en 2000, lo que probablemente refleja la práctica de conservación del manejo forestal. Las simulaciones para 2011 y 2014 indican alta escorrentía en el municipio de Chilchota debido a la modificación de sus áreas forestales y agricultura tradicional para acomodar el cultivo del aguacate y bayas.

Palabras clave: Modelo SWAT, redes neuronales artificiales, mapeo digital.

Received: 06/11/2019

Accepted: 10/02/2021

\section{Introduction}




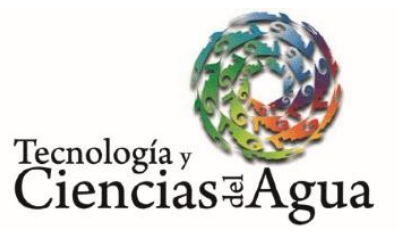

2022, Instituto Mexicano de Tecnología del Agua

Open Access bajo la licencia CC BY-NC-SA 4.0

(https://creativecommons.org/licenses/by-ncsa/4.0/)

Land-use change affects surface runoff dynamics, and the quantification of its effect is important for understanding the hydrological processes of river basins (Hundecha \& Bárdossy, 2004). This change also alters climate processes at different scales and increases vulnerability to climate change (Cuo, 2016). One of the major land-use and land-cover changes is the conversion of forests over time, as a consequence of the agricultural activities and urban area expansion (Foley et al., 2005). In recent decades, studies have assessed the extent and condition of forest resources in the world and found that the main cause of deforestation comes from the need to obtain more arable land, with a strong tendency toward over-exploitation (FAO, 2001). Forest systems not only have a biological functionality but also regulate the export of nutrients, carbon storage, and their roots play an important role in providing resistance to soil erosion by reducing runoff velocity and binding the soil (Kauffman, Hughes, \& Heider, 2009; DeFries, Rudel, Uriarte, \& Hansen, 2010).

The Duero River basin in Mexico is facing serious environmental problems, such as water and soil pollution, overexploitation of groundwater, and changes in the use of soil and vegetation. EstradaGodoy et al. (2013) reported the increasing vulnerability of the aquifer, which is mainly caused by overexploitation and the impact of agrochemicals used in the region. The chemical characteristics of ground and surface water resources have also been studied for different years and the results showed that groundwater has relatively good quality, while surface water is slightly or moderately contaminated (Silva et al., 
Tecnología y

Ciencias $\stackrel{\Xi}{\Im}$ Aua
2022, Instituto Mexicano de Tecnología del Agua

Open Access bajo la licencia CC BY-NC-SA 4.0

(https://creativecommons.org/licenses/by-ncsa/4.0/)

2013). Silva-García et al. (2016) analyzed the operation, quality, and quantity of water from 49 springs, of which 27 are located upstream, in the municipality of Chilchota. Results showed that these springs have good chemical quality in general but are susceptible to punctual and diffuse pollution (wastewater, agricultural activities, recreational and urban growth). Cruz-Cárdenas, Silva, Ochoa-Estrada, Estrada-Godoy, and Nava-Velázquez (2017) defined environmental variable units using climate, topography, soil, and water properties and used remote sensing data to quantify urban growth. They classified five environmental units based on the water quality of the sampled wells and defined their uses: values from 0.75 to $2.25 \mu \mathrm{S} \mathrm{cm}-1$ are suitable for irrigation under certain regulations, while values $>2.25 \mu \mathrm{S} \mathrm{cm}-1$ are not recommended for some uses. The classified environmental units allow for the allocation of conservation areas and the use of resources.

Regarding natural resources evaluation, previous studies have focused on developing methodologies and tools that can be used to model the environment, such as digital mapping and hydrological modeling. The former evaluates and measures the change in land use and vegetation using remote sensing data and computer algorithms, which can be used to discriminate different land covers within a satellite image (Congalton, 1991; Cruz-Cárdenas et al., 2010). Meanwhile, hydrological models are simplified representations of the processes that occur in a basin. In this context, it is important to maintain a holistic view to characterize the dynamics of the model's attributes and predict how processes will behave via simulation (Soetaert \& Herman, 2008; Jiménez-Valverde, Acevedo, 
Tecnología y

Ciencias $\stackrel{\Xi}{\Im}$ Agua
2022, Instituto Mexicano de Tecnología del Agua

Open Access bajo la licencia CC BY-NC-SA 4.0

(https://creativecommons.org/licenses/by-nc$\mathrm{sa} / 4.0 /)$

Barbosa, Lobo, \& Real, 2013). Most hydrological models are based on the water balance equation to study cause and effect relationships, which allows to estimate the availability of water in a region under the principle of continuity, i.e., the models quantify inputs and outputs, as well as the changes in storage within the basin (Hernández, Scarpare, \& Seabra, 2018).

Studies on hydrological modeling have been conducted in different parts of the world. These studies have analyzed the impact of changes in vegetation on the hydrological process in the basin(Zhou et al., 2013; Gebremicael, Mohamed, Betrie, Van-derZaag, \& Teferi, 2013; Brouziyne, Abouabdillah, Bouabid, Benaabidate, \& Oueslati, 2017). The development of hydrological models, such as the soil and water assessment tool (SWAT), has provided the capability to simulate hydrological processes (Xiong, Xu, Ren, Huang, \& Huang, 2019), obtain estimates with acceptable precision (Nie et al., 2011; Baker \& Miller, 2013; Ha, Bastiaanssen, Griensven, Van Dijk, \& Senay, 2018), and facilitate decision making in terms of the adequate use of water resources (Jayakrishnan, Srinivasan, Santhi, \& Arnold, 2005).

The SWAT model is a continuous dynamic model based on the mathematical descriptions of physical, bio-geochemical and hydrochemical processes and has been used for different hydrographic basins of Mexico and the world (Torres-Benites, Fernández-Reynoso, Oropeza-Mota, \& Mejía-Saenz, 2004; Barrios \& Urribarri, 2010; Arnold et al., 2012; Bautista-Ávalos, Cruz-Cárdenas, G., Moncayo-Estrada, Silva, \& 
Tecnología y

Ciencias $₫$ Agua
2022, Instituto Mexicano de Tecnología del Agua

Open Access bajo la licencia CC BY-NC-SA 4.0

(https://creativecommons.org/licenses/by-nc$\mathrm{sa} / 4.0 /$ )

Estrada-Godoy, 2014; Meng, Yu, \& Liu, 2015). It is designed to evaluate the effect of topography, soils, land use, and climate on the hydrologic response of ungauged basins, the data used to generate the input parameters may be scarce or absent (Srinivasan, Zhang, \& Arnold, 2010). Depending on the complexity of the study and the data available, this model defines the hydrologic response units (HRUs) to show differences in transpiration and other hydrological conditions for the diverse soil characteristics of land use and vegetation (Neitsch, Arnold, Kiniry, Srinivasan, \& Williams, 2010).

Because there is a conversion of vegetation by human activities in the Duero River basin, the main aim of this study was to evaluate the variation of surface runoff in four scenarios of change in land use and vegetation (1983, 2000, 2011, and 2014 ) with the SWAT model.

\section{Materials and methods}

\section{Study area}


Tecnología y

Ciencias $₫$ Agua
2022, Instituto Mexicano de Tecnología del Agua

Open Access bajo la licencia CC BY-NC-SA 4.0

(https://creativecommons.org/licenses/by-nc$\mathrm{sa} / 4.0 /$ )

The Duero River basin is located on the northwest of the state of

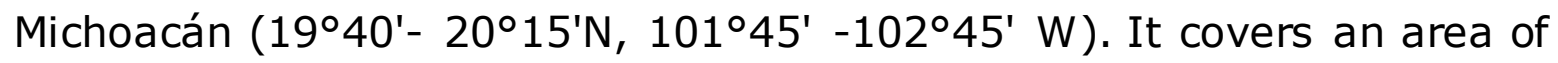
$2531.3 \mathrm{~km}^{2}$ with an elevation range from 1500 to $2400 \mathrm{~m}$ (Figure 1). The area is characterized by a subhumid climate ((A) C (wo), C (w1), and C (w2)). The basin is a predominantly volcanic environment with stratovolcano structures (Silva \& Ramos, 1998). Vertisol is the dominant agricultural soil type in the valleys to produce vegetables, basic grains, and berries and it covers over $50 \%$ of the basin area, meanwhile, the Andosol soil located in the mountains is used for avocado production (Estrada-Godoy et al., 2013). 
Tecnología y

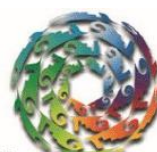

Ciencias
2022, Instituto Mexicano de Tecnología del Agua Open Access bajo la licencia CC BY-NC-SA 4.0 (https://creativecommons.org/licenses/by-ncsa/4.0/)

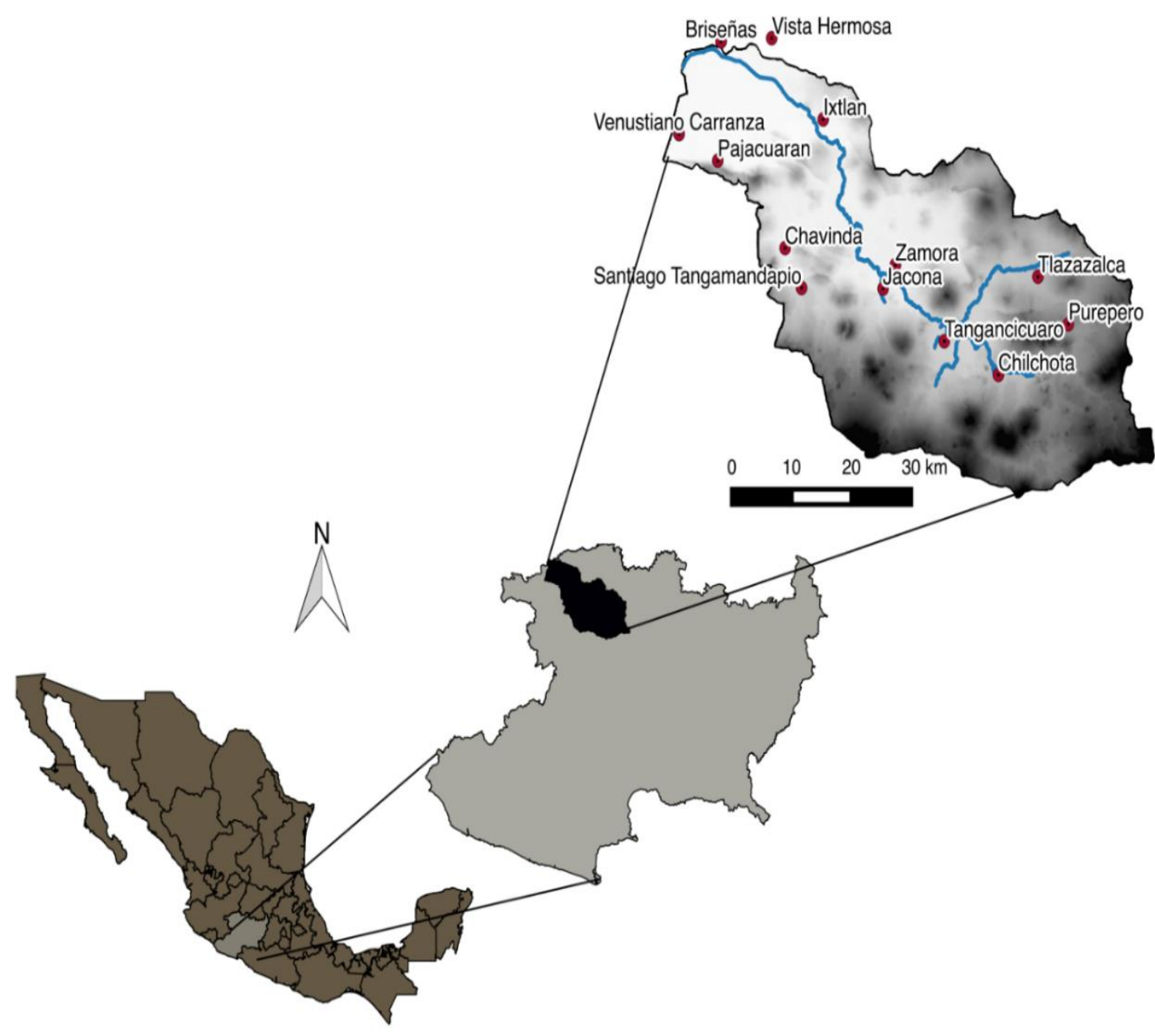

Figure 1. Location of the Duero River basin, Michoacán, Mexico. 


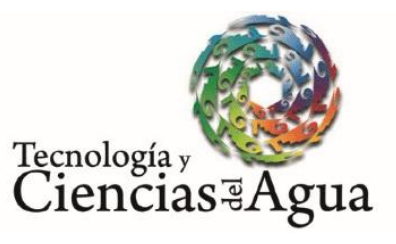

2022, Instituto Mexicano de Tecnología del Agua

Open Access bajo la licencia CC BY-NC-SA 4.0

(https://creativecommons.org/licenses/by-nc$\mathrm{sa} / 4.0 /)$

\section{Topographic attributes}

The digital elevation model (DEM) of the basin was obtained from the Mexican Territory Elevations Model (INEGI, 2014), with a pixel resolution of $30 \mathrm{~m} \times 30 \mathrm{~m}$. This dataset was used to generate areas of three slope intervals: < $5 \%$, between 5 and $10 \%$, and > $10 \%$ (Neitsch et al., 2010).

\section{Climate data}

Fourteen climate variables were used to feed the SWAT model (Neitsch et al., 2010). The meteorological information was obtained from the Rapid Extractor of Weather Information (ERIC III version 2.0 of the Mexican Institute of Water Technology). A filter was applied to select stations that were at least 20 years old and had data with $>80 \%$ of the available records per year. In the end, 20 meteorological stations within the basin were selected. The solar radiation, dew point, and wind speed variables were calculated based on the data provided by 10 nodes of the National Center for Environmental Prediction (NCEP, 2014). The mean annual temperature and accumulated precipitation were obtained from the whole 
Tecnología y

Ciencias ฐึgua
2022, Instituto Mexicano de Tecnología del Agua

Open Access bajo la licencia CC BY-NC-SA 4.0

(https://creativecommons.org/licenses/by-ncsa/4.0/)

database from the selected meteorological stations.

\section{Soil Properties}

The soil profiles were described from six sites chosen based on the soil units map of INIFAP and Conabio (1995). Soil samples were collected and analyzed from each soil layer according to the Official Mexican Standard NOM-021-RECNAT-2000 (Semarnat, 2002). The soil properties required for the model are depth, apparent density, saturated hydraulic conductivity, soil erosion, organic carbon content, rock fragment content, electrical conductivity, available water capacity, and percentage of sand, silt, and clay.

\section{Land use}

Digital mapping technique was used to obtain and quantify different types of land use in the Duero River basin. This is the recommended method 
Tecnología y

Ciencias $₫$ Agua
2022, Instituto Mexicano de Tecnología del Agua

Open Access bajo la licencia CC BY-NC-SA 4.0

(https://creativecommons.org/licenses/by-ncsa/4.0/)

when the area is known because it allows the selection of the classes to be analyzed (Chuvieco, 2002). The remote sensing data used include Landsat 5, Landsat 7, and Landsat 8 satellite images for four periods $(1983,2000,2011$, and 2014) with a spatial resolution of $30 \times 30 \mathrm{~m}$. The DEM was also used in the digital mapping process to improve the accuracy of the maps (Cruz-Cárdenas et al., 2010).

A total of 250 sampling points were categorized into the following classes of land use: agriculture (A), pine-oak forest (POF), grassland (G), shrub (M), and urban area (UA). Seventy percent of the sampling sites were randomly selected to perform the automated mapping using five algorithms: artificial neural networks (ANN), decision trees (CTA), minimum distance (DM), maximum likelihood (ML), and parallelepiped (PP) (Lo \& Yeung, 2007). After the classification, the remaining $30 \%$ of the points were used to validate the land use and vegetation maps. A confusion matrix was generated to measure the reliability of the maps using the overall accuracy and the kappa coefficient (Congalton, 1991).

\section{Calibration and validation of the SWAT model}

The SWAT model divides the basin into sub-basins based on the digital 
Tecnología y

Ciencias $₫$ Agua
2022, Instituto Mexicano de Tecnología del Agua

Open Access bajo la licencia CC BY-NC-SA 4.0

(https://creativecommons.org/licenses/by-nc$\mathrm{sa} / 4.0 /$ )

elevation model. A flow accumulation layer will be generated from one layer of flow direction. A flow network is created, and the main channel is divided and ordered into continuous segments. The accumulation points of each network are calculated, and the delimitation of sub-basins is carried out. Then, these sub-basins are divided into hydrologic response units (HRUs) according to the topography, land use, and soil type. Finally, with the SWAT input files (Arnold et al., 2012), the simulation, calibration, and validation of the model are implemented (Figure 2). 
Tecnología y

Ciencias $₫$ đAgua
2022, Instituto Mexicano de Tecnología del Agua Open Access bajo la licencia CC BY-NC-SA 4.0 (https://creativecommons.org/licenses/by-nc$\mathrm{sa} / 4.0 /)$

\section{Input Data}

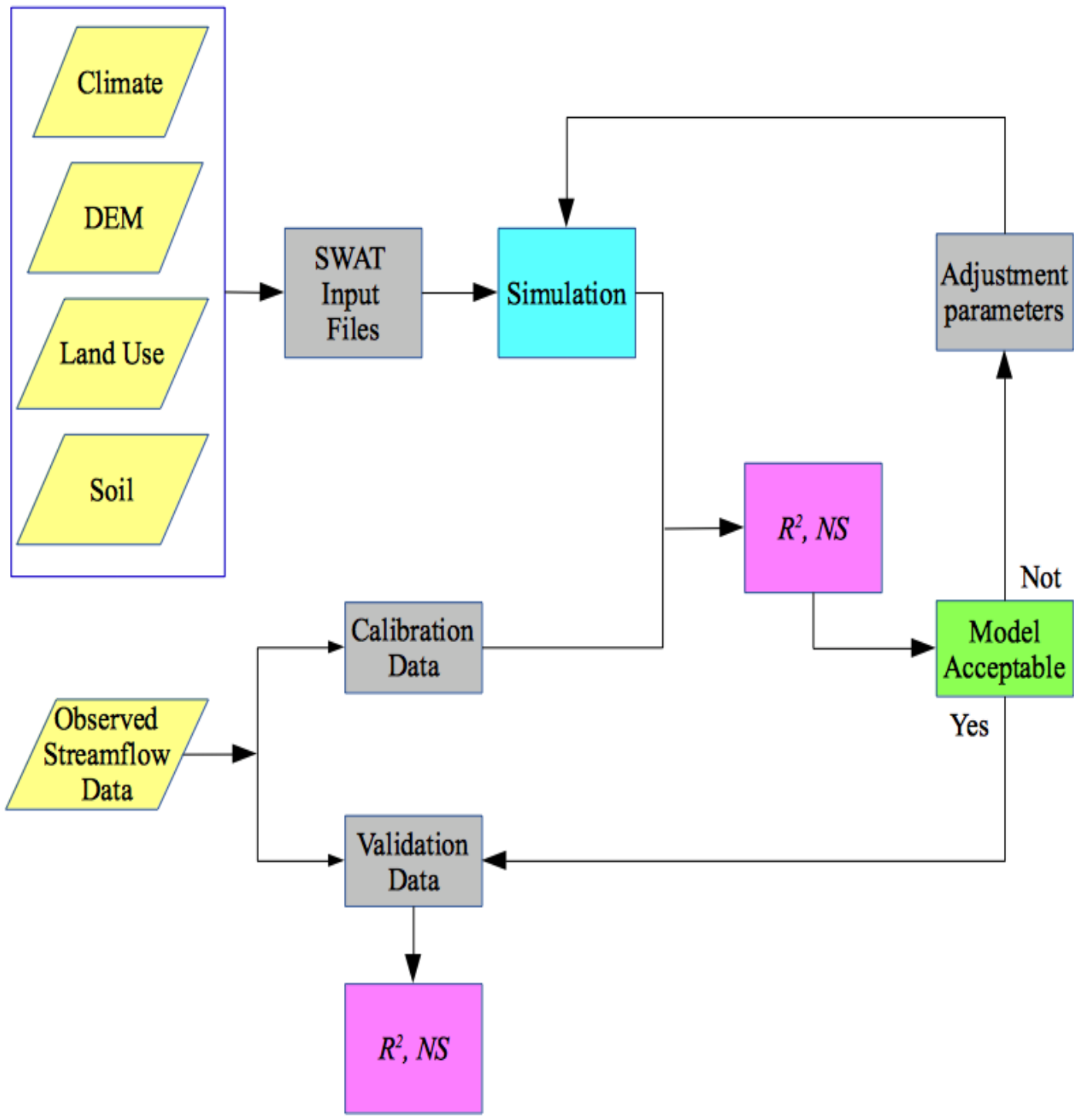

Figure 2. Flowchart of the model construction, calibration, and validation processes. DEM = digital elevation model; $R^{2}=$ coefficient of determination; NS = Nash-Sutcliffe efficiency. 
Teçnología y

Ciencias $\stackrel{\unlhd}{\unlhd}$ gua
2022, Instituto Mexicano de Tecnología del Agua

Open Access bajo la licencia CC BY-NC-SA 4.0

(https://creativecommons.org/licenses/by-nc$\mathrm{sa} / 4.0 /$ )

The calibration and validation processes were performed using a partition of the observed data available. The calibration was configured manually, adjusting the values of the curve number parameter (NC2) (Boyle, Gupta, \& Sorooshian, 2000; Arnold et al., 2012). The streamflow records (in $\mathrm{m}^{3} \mathrm{~s}^{-1}$ ) of the hydrological stations' network from the National Bank of Surface Water (NBSW) were used for model calibration and validation. Twenty-one hydrological stations are in the basin, however, six were selected because they have records from 20 years (1980-2000).

The calibration of the 1983 land-use scenario was done using the monthly average streamflow from 1980-1982, and the validation with the streamflow from 1983-1984. In the 2000 land-use scenario, the streamflow from 1995 to 1997 was used for calibration, meanwhile, the streamflow from 1998 to 1999 was used for validation. In both scenarios, the SWAT-estimated runoff was compared to the observed streamflow (NBSW). The Nash-Sutcliffe efficiency (NS) (Nash \& Sutcliffe, 1970) and the coefficient of determination $\left(R^{2}\right)$ (Krause, Boyle, \& Bäse, 2005) were calculated to measure the goodness of fit. These coefficients were chosen as suitable methods for judging the goodness of fit of a hydrological model (Nash \& Sutcliffe, 1970).

\section{Results}


Tecnología y

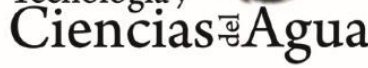

2022, Instituto Mexicano de Tecnología del Agua

Open Access bajo la licencia CC BY-NC-SA 4.0

(https://creativecommons.org/licenses/by-ncsa/4.0/)

The analysis of the temperature and precipitation data from the 20 meteorological stations showed that both variables changed in the Duero River basin (Figure 3). Particularly, the mean annual temperature showed an increase of $0.8^{\circ} \mathrm{C}$, and the precipitation decreased by $90 \mathrm{~mm}$ over 60 years. 
Tecnología y

Ciencias $₫$ Agua
2022, Instituto Mexicano de Tecnología del Agua Open Access bajo la licencia CC BY-NC-SA 4.0 (https://creativecommons.org/licenses/by-nc$\mathrm{sa} / 4.0 /$ )

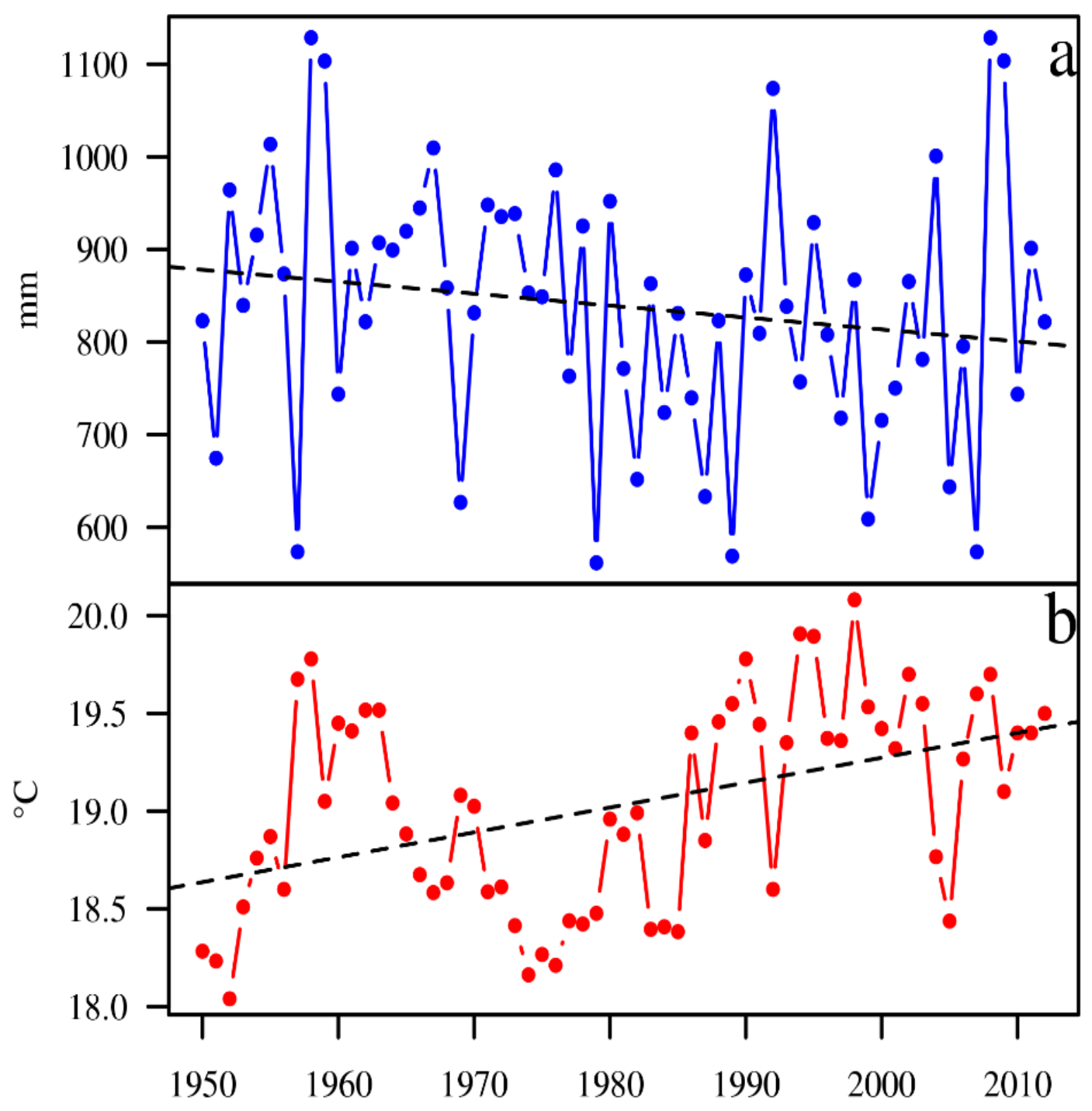

Year

Figure 3. Climatic variables of the Duero River basin (60 years): a) Annual precipitation; b) annual average temperature.

The five algorithms used for the digital mapping yielded a 
Tecnología y

Ciencias Agua
2022, Instituto Mexicano de Tecnología del Agua

Open Access bajo la licencia CC BY-NC-SA 4.0 (https://creativecommons.org/licenses/by-nc$\mathrm{sa} / 4.0 /$ )

more than $60 \%$ agreement between classified classes and validated data. Among these methods, both ANN and $M L$ reach the classification accuracy of $>80 \%$. Based on the expert knowledge of the study area, we considered that the maps generated by the ANN method better represented the distribution of land use (Figure 4).

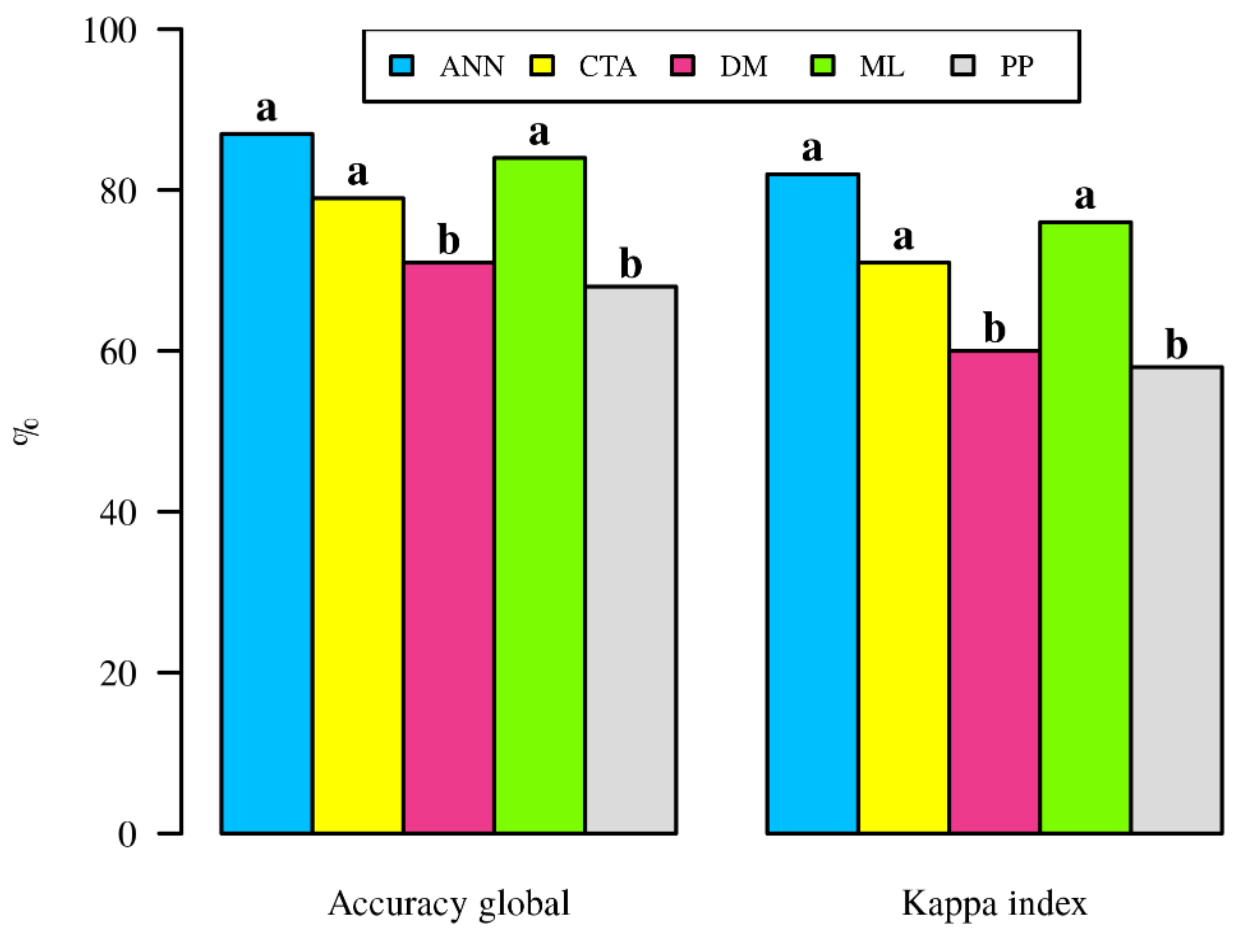

Test

Figure 4. Mean comparison ( $p$-value $=0.05$; different letters represent a significant difference), with global accuracy and kappa index, of five classifiers for digital mapping. ANN = artificial neural networks; CTA = 
Tecnología y

Ciencias $\stackrel{\unlhd}{\triangleleft}$ gua
2022, Instituto Mexicano de Tecnología del Agua

Open Access bajo la licencia CC BY-NC-SA 4.0

(https://creativecommons.org/licenses/by-nc$\mathrm{sa} / 4.0 /$ )

decision trees; $\mathrm{DM}=$ minimum distance $\mathrm{ML}=$ maximum likelihood; $\mathrm{PP}$ $=$ parallelepiped. The best algorithms for the classification were neural networks and maximum likelihood, with concordance values above 84 and $89 \%$, respectively, in the classification of pixels.

The distributions of the five classes of land use from 1983 to 2014 are shown in Figure 5. From 1983 to 2000, land covers of G, S, and UA increased $15.5,8.8$, and $0.3 \%$, respectively. In contrast, land use of A and POF showed losses of 15.2 and $9.3 \%$, respectively. This period presented the greatest loss of pine-oak forest over the 17 years. From 2000 to 2011, the land covers with positive rates were A (3.1\%), POF $(2.4 \%)$ and UA (0.4\%), while S (2.2\%) and G (3.8\%) had losses. From 2011 to 2014 , the land covers with a positive rate corresponded to A (0.2 $\%)$, G (2.6 \%) and UA (0.3\%), while POF (2.4\%) and S (0.7\%) had negative rates. 
Tecnología y

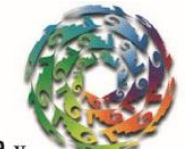

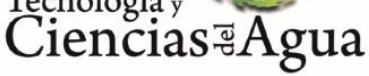

2022, Instituto Mexicano de Tecnología del Agua Open Access bajo la licencia CC BY-NC-SA 4.0 (https://creativecommons.org/licenses/by-ncsa/4.0/)

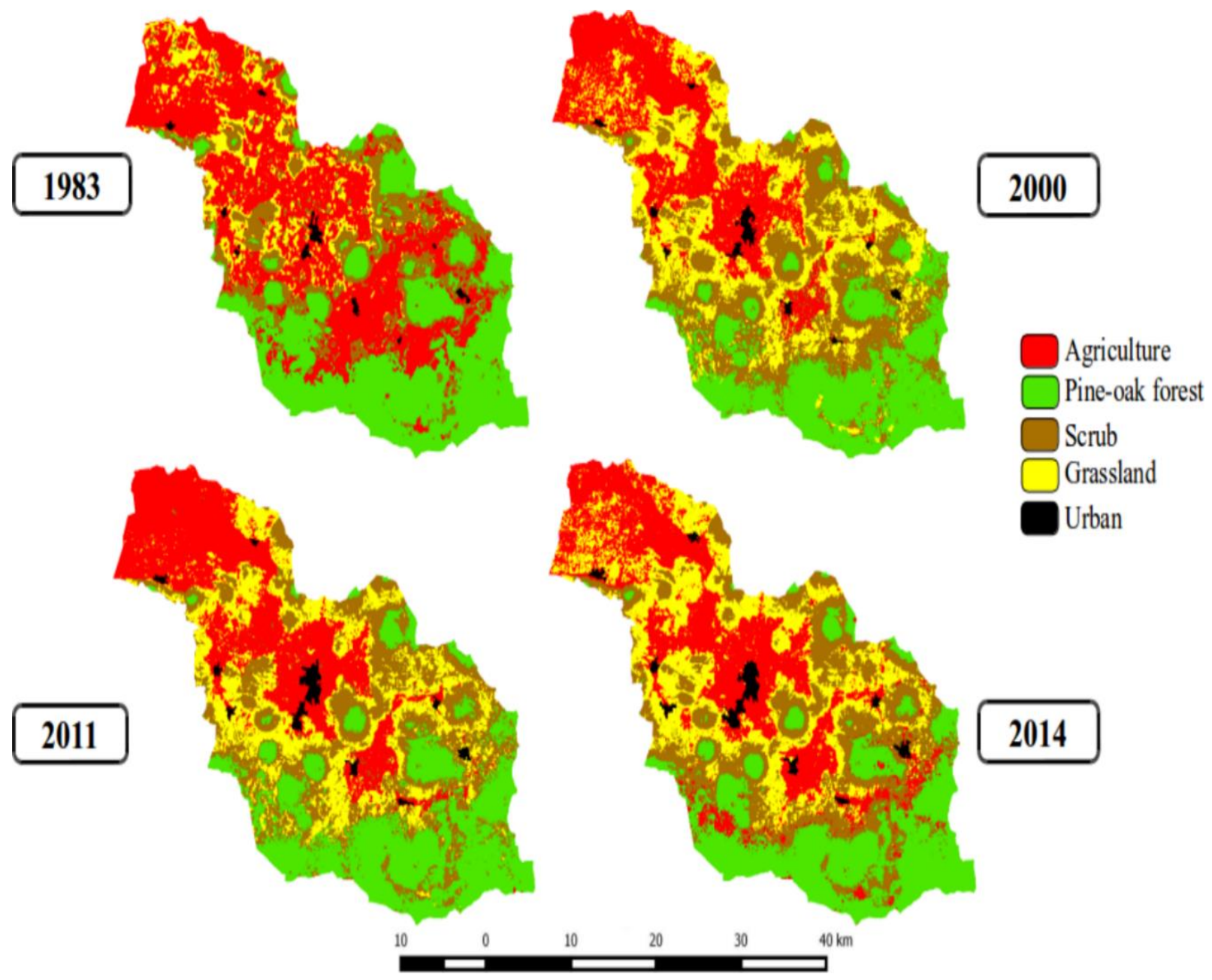

Figure 5. Land use for four scenarios for the Duero River basin. Maps generated using artificial neural networks were used.

In the SWAT model, the basin was divided into 25 sub-basins and at least 132 HRUs. No changes were made to the input parameters of the first simulation model for the land-use scenario of 1983. 
Tecnología y

Ciencias $₫$ Agua
2022, Instituto Mexicano de Tecnología del Agua

Open Access bajo la licencia CC BY-NC-SA 4.0

(https://creativecommons.org/licenses/by-nc$\mathrm{sa} / 4.0 /$ )

Figure 6a shows a comparison between the observed and simulated streamflow that represents a clear difference between these two values. Although a high coefficient of determination was obtained (0.93) (Table 1 ), the Nash-Sutcliffe coefficient (NS) is only -2.24 , indicating a poor predictive capacity of the model and that an adjustment is necessary. The three-year streamflow records (1980-1982) were used to calibrate the model, and a manual adjustment was done using the curve number values. Table 1 shows the summary of the calibration and validation models. In the calibration, a coefficient of determination of $R^{2}=0.92$ and a NSE of 0.51 imply that the model was still poor. For the validation, twoyear data (1983-1984) were used, with $R^{2}=0.96$ and NSE $=0.61$. 
Tecnología y

Ciencias 고의
2022, Instituto Mexicano de Tecnología del Agua Open Access bajo la licencia CC BY-NC-SA 4.0 (https://creativecommons.org/licenses/by-ncsa/4.0/)

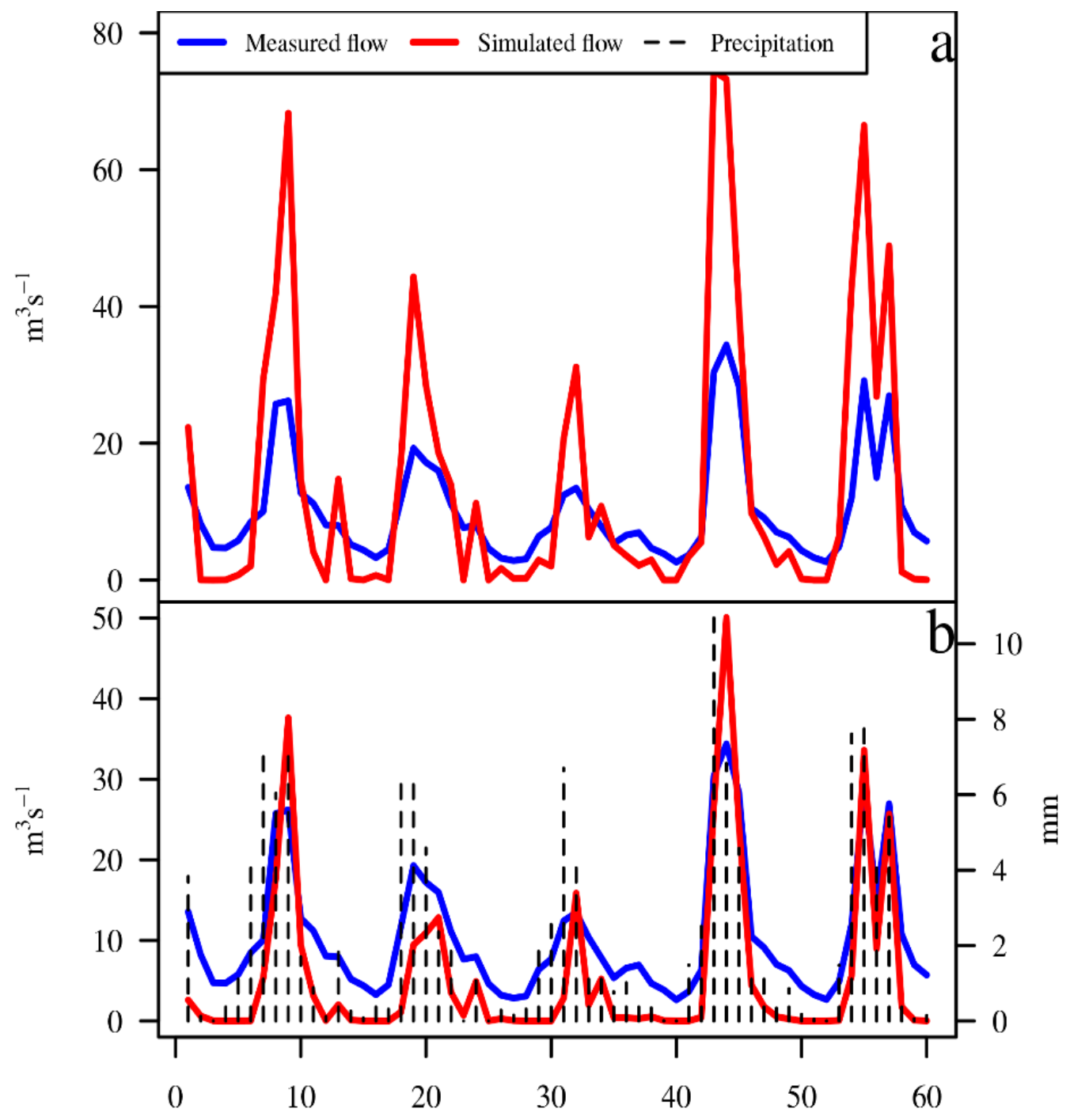

Month

Figure 6. Comparison of observed and calculated monthly surface flow for the Duero River basin for the period from 1980-1984. a) First simulation; b) calibration (1-36 month) and validation (37-60 month). Additionally, the precipitation values are shown. 
Tecnología y

Ciencias Agua
2022, Instituto Mexicano de Tecnología del Agua Open Access bajo la licencia CC BY-NC-SA 4.0 (https://creativecommons.org/licenses/by-nc$\mathrm{sa} / 4.0 /$ )

After the model was calibrated and validated, the observed and measured streamflow values were adjusted (Figure 6b). The peaks in the precipitation values indicate the wet months of each period.

Table 1. Summary of the calibration and simulation of the estimated and observed values of the runoff.

\begin{tabular}{|l|c|c|c|c|}
\hline & Scenario 1983 & \multicolumn{3}{|c|}{ Scenario 2000} \\
\cline { 2 - 5 } & $R^{2}$ & NS & $R^{2}$ & NS \\
\hline First simulation & 0.93 & -2.24 & 0.96 & -2.50 \\
\hline Calibration & 0.92 & 0.51 & 0.94 & 0.54 \\
\hline Validation & 0.96 & 0.61 & 0.91 & 0.70 \\
\hline \multicolumn{2}{|c|}{$R^{2}=$ coefficient of determination; NS = Nash-Sutcliffe efficiency. } \\
\hline
\end{tabular}

In the first simulation for the 2000 land-use scenario, the $R^{2}$ was 0.96 and the NS was -2.50 (Table 1 ). The calibration stage with data from 1995-1997 presented an $R^{2}$ of 0.94 and NS of 0.54 (Table 1). The validation for 1998-1999 presented an $R^{2}$ of 0.91 and NS of 0.70 (Table 1). When compared the streamflow this period also showed a better adjustment than in the first simulation (Figure 7). 


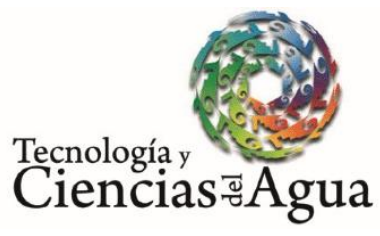

2022, Instituto Mexicano de Tecnología del Agua Open Access bajo la licencia CC BY-NC-SA 4.0 (https://creativecommons.org/licenses/by-ncsa/4.0/)

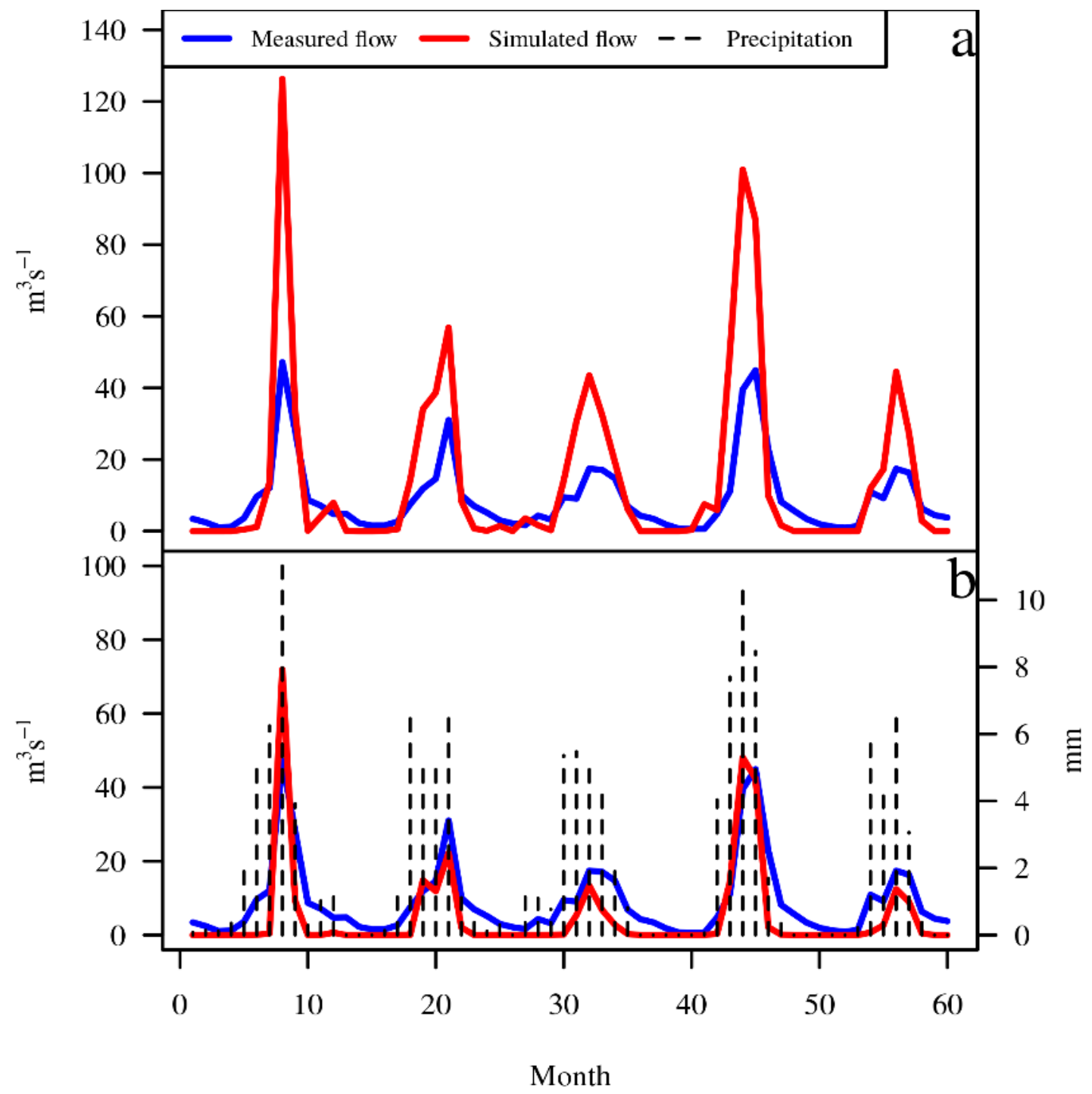

Figure 7. Comparison of observed and calculated surface flow for the Duero River basin for the period from 1995-1999. a) First simulation; b) calibration (1-36 month) and validation (37-60 month). Additionally, precipitation values are shown.

The initial NC2 values for both periods were 87 , and the endpoints 
Tecnología y

Ciencias $₫$ Agua
2022, Instituto Mexicano de Tecnología del Agua

Open Access bajo la licencia CC BY-NC-SA 4.0

(https://creativecommons.org/licenses/by-nc$\mathrm{sa} / 4.0 /$ )

were 73 for 1983 and 62 for 2000. In the case of the 2011 and 2014 periods, only the runoff was projected because of the lack of streamflow data available to perform the calibration and validation of the models.

Figure 8 shows the amount of surface runoff for each period. In the 1983 scenario $76 \%$ of subbasins had runoff of less than $10 \mathrm{Dam}^{3}$ (cubic decameter) of water, while for 2000 , this increased to $84 \%$, aspect that continued in the following scenarios. It was noted that in 1983 the subbasin number 16 had runoffs of approximately 30 Dam $^{3}$ of water, but in 2000, the same subbasin reduced its runoff to less than $10 \mathrm{Dam}^{3}$. In the 2011 and 2014 scenarios, the maximum runoff occurred in the highlands of the basin. 
Tecnología y

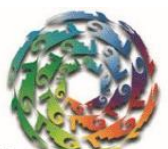

Ciencias $₫$ Agua
2022, Instituto Mexicano de Tecnología del Agua

Open Access bajo la licencia CC BY-NC-SA 4.0

(https://creativecommons.org/licenses/by-nc$\mathrm{sa} / 4.0 /$ )

\section{3}
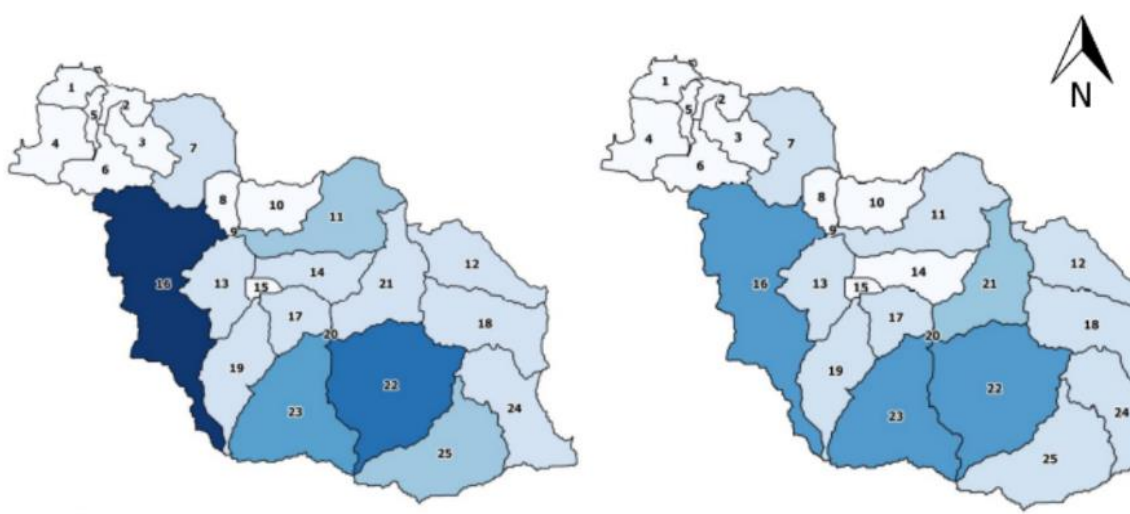

2000

2011
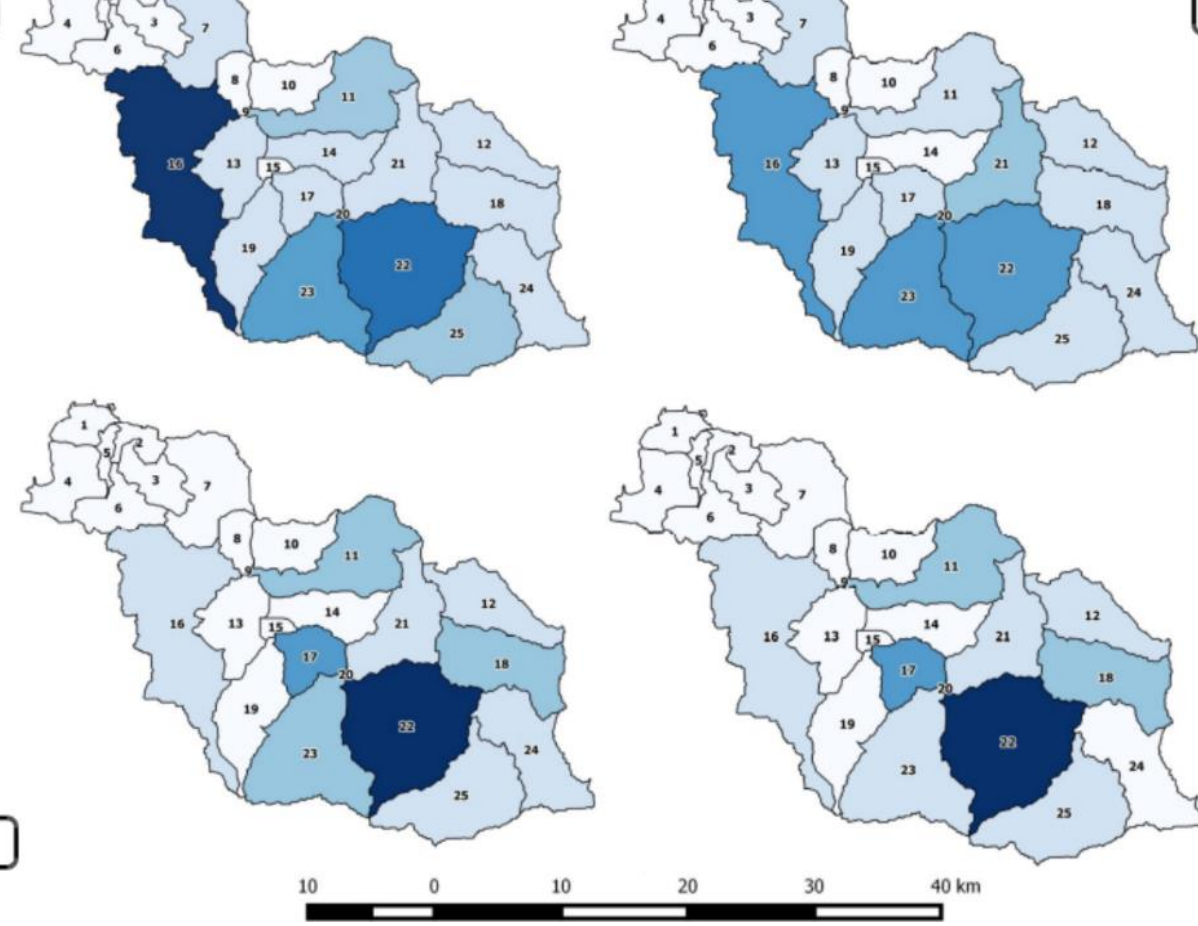

\section{Runoff (Dam $\left.{ }^{3}\right)$}

$\square \quad 30-4895$

4895 - 9761

$9761-14626$

$14626-19491$

$19491-24356$

$24356-30000$

Figure 8. Surface runoff in the Duero River basin during different periods. Dam $^{3}=$ cubic decameter.

\section{Discussion}

The Intergovernmental Panel on Climate Change (IPCC) has projected annual average temperature changes under different scenarios of 
Tecnología y

Ciencias $\stackrel{\unlhd}{\unlhd}$ gua
2022, Instituto Mexicano de Tecnología del Agua

Open Access bajo la licencia CC BY-NC-SA 4.0

(https://creativecommons.org/licenses/by-ncsa/4.0/)

greenhouse gas emissions and concentrations, with a probable increase range of $0.3^{\circ} \mathrm{C}$ to $0.7^{\circ} \mathrm{C}$ (IPCC, 2014). In the Duero River basin, according to the projected values, there was an increase of $0.8^{\circ} \mathrm{C}$ in the period from 1950 to 2010, which, at the regional level, could be attributed to the change in land use due to different anthropogenic activities (Magaña, 2004). The aforementioned factors influence the climate, which determines the adaptation of living organisms and a variety of climatic zones with different temperature, humidity, luminosity, and precipitation characteristics, being conducive to the natural selection of species (Valladares et al., 2014).

The land use maps presented high accuracy because the kappa values were between 0.73 to 0.84 . According to Castillejo-González et al. (2009), and accuracy between 82 to $89 \%$ for the map classification is acceptable. With both measurements of the goodness of fit, it is possible to confirm that within the remote sensing data, the defined classes were discriminated.

Bravo, Mendoza, and Medina (2009) mentioned that between the 1960 s and 1980s, deforestation in the state of Michoacán was intensified. Mas-Caussel, Velásquez-Montes, and Fernández-Vargas (2005) reported that between 1976 and 2000, there was a conversion of 8500 ha of temperate forests to avocado plantations per year. This is because there are agroclimatic conditions in the Duero River basin for the establishment of avocado orchards, promoting a decrease in pine-oak forests (Fregoso, Velázquez, Bocco, \& Cortéz, 2001). The expansion of this crop has led to deforestation processes, which, as in other basins with similar 
Tecnología y

Ciencias $\stackrel{\Xi}{\Im}$ Agua
2022, Instituto Mexicano de Tecnología del Agua

Open Access bajo la licencia CC BY-NC-SA 4.0

(https://creativecommons.org/licenses/by-nc$\mathrm{sa} / 4.0 /)$

characteristics, have had negative effects such as soil degradation, aquifer reduction, biodiversity loss, and plague emergence (PinedaJaimes, Bosque-Sendra, Gómez-Delgado, \& Plata-Rocha, 2009). The deforestation process impacts at all scales: locally, with changes in the microclimate and detriment of the biodiversity; regionally, it affects the functioning of hydrographic basins; and at the global level, it contributes to emissions of greenhouse gases (Bocco, Mendoza, \& Masera, 2001; Tölle, Engler, \& Panitz, 2017). These changes can strongly degrade natural resources and increase the vulnerability of adjacent populations (DeFries et al., 2010; Gauquelin et al., 2018).

The first notable streamflow simulation differences between observed and simulated values promoted the implementation of a sensitivity analysis. Ma et al. (2000) recommended identifying the key and precision parameters to achieve a good calibration; therefore, a better parameterization of the model under local conditions and the consequent reduction of the prediction uncertainty can be achieved. The value of the selected parameter was chosen to be within its respective ranges of uncertainty to avoid overestimating or underestimating the outputs of the model. The SWAT model creates parameter tables related to the hydrological processes of the basin; the runoff curve number is one of the most sensitive parameters that affect the values of drained volumes (Arnold et al., 2012). The NC2 values of the Soil Conservation Service are assigned according to the soil type and vegetation cover with a variation of $\pm 10 \%$, which is an acceptable range of error. Arnold et al. (2012) indicated that adjusting the parameters by $\pm 10 \%$ is an acceptable 
Tecnología y

Ciencias $\stackrel{\unlhd}{\unlhd}$ gua
2022, Instituto Mexicano de Tecnología del Agua

Open Access bajo la licencia CC BY-NC-SA 4.0

(https://creativecommons.org/licenses/by-ncsa/4.0/)

practice for the values estimated by the SW AT model compared with those observed. The NC2 values of the models of the present study were 73 and 62 for the years 1983 and 2000, respectively. These values are within the ranges reported for each land use and vegetation. The values obtained for each land use and vegetation used in the basin were within their respective ranges.

The values obtained in the validation stage indicated that the models are very good according to the scale proposed by Nash and Sutcliffe (1970), while the $R^{2}$ values can be considered good only when they are from 0.7 to 0.9 , (i.e., close to 1 ), providing an estimation based on the observed values replicated by the model (Krause et al., 2005).

According to Choi (2007), anthropic alterations to a vegetal cover increase drained volumes because the runoff coefficient is related to the texture and land use. In the periods from 2011 to 2014, some areas in the Duero River basin experienced increased surface runoff because of changes in land use and soil characteristics, such as clay texture and relief, which altered the infiltration capacity of the basin. This reduces the availability of water by the conversion of pastures to crops (Smith et al., 2016). These conversions lead to a drastic reduction in the water supply at local and national scales, changing the hydrologic cycle balance and increasing the impact of global warming (Rasmussen et al., 2014). Therefore, it is suggested that land cover/use changes should be characterized about anthropogenic activities in space and time to achieve conservation and the sustainable management of natural resources (Mawdsley, O’Malley, \& Ojima, 2009). 
Tecnología y

Ciencias $\stackrel{\Xi}{\unlhd}$ gua
2022, Instituto Mexicano de Tecnología del Agua

Open Access bajo la licencia CC BY-NC-SA 4.0

(https://creativecommons.org/licenses/by-ncsa/4.0/)

\section{Conclusions}

The analysis of climatic variables in the Duero River basin showed a temperature increase of $0.8^{\circ} \mathrm{C}$ and a decrease in precipitation of $90 \mathrm{~mm}$ from 1950 to 2010. The Duero River basin presents agro-climatic conditions for the development and growth of avocados. In this scenario, the pine-oak forest has been affected. Urban growth has affected only 1 $\%$ of the land area in the basin, but each year the impact of urban growth expands towards areas devoted to agriculture.

The results obtained from the SWAT model are satisfactory, including the $R^{2}$ value of 0.9 and the NS of 0.7 , which indicate that it was a good model for simulating the behavior of the studied hydrological process. The conversion of land use and vegetation significantly affects the volume of surface runoff. Recovery of the vegetation in bare areas may serve to slow down the surface runoff, allowing infiltration and the reduction of water erosion. 
2022, Instituto Mexicano de Tecnología del Agua

Tecnología y

Ciencias $\stackrel{\Xi}{\triangleleft}$ gua
Open Access bajo la licencia CC BY-NC-SA 4.0

(https://creativecommons.org/licenses/by-nc$\mathrm{sa} / 4.0 /$ )

\section{Appendix 1. Summary of SWAT model parameters}

\begin{tabular}{|c|c|c|}
\hline Parameter & Description & Value \\
\hline SOL_BD & Soil bulk density $\left(\mathrm{g} \mathrm{cm}^{-3}\right)$ & $0.68-1.29$ \\
\hline SOL_CBN & $\begin{array}{l}\text { Soil organic carbon content } \\
(\%)\end{array}$ & $0.53-11.00$ \\
\hline SOL_K & $\begin{array}{l}\text { Soil saturation conductivity } \\
(\mathrm{mm} \mathrm{hr}-1)\end{array}$ & $0.29-13.21$ \\
\hline SOL_ALB & Soil albedo & $0.01-0.42$ \\
\hline CN2 & $\begin{array}{l}\text { Runoff curve number of } \\
\text { moisture condition II }\end{array}$ & $62-87$ \\
\hline ESCO & $\begin{array}{l}\text { Soil evaporation compensation } \\
\text { factor }\end{array}$ & 0.20 \\
\hline EPCO & $\begin{array}{l}\text { Plant uptake compensation } \\
\text { factor }\end{array}$ & 1.00 \\
\hline
\end{tabular}


2022, Instituto Mexicano de Tecnología del Agua

Tecnología y Open Access bajo la licencia CC BY-NC-SA 4.0 (https://creativecommons.org/licenses/by-nc$\mathrm{sa} / 4.0 /)$

\section{References}

Arnold, J. G., Moriasi, D. N., Gassman, P. W., Abbaspour, K. C., White, M. J., Srinivasan, R., \& Kannan, N. (2012). SWAT: Model use, calibration, and validation. Transactions of the ASABE, 55(4), 1491-1508. DOI: $10.13031 / 2013.42256$

Baker, T. J., \& Miller, S. N. (2013). Using the Soil and Water Assessment Tool (SWAT) to assess land use impact on water resources in an East African watershed. Journal of Hydrology, 486, 100-111. DOI:10.1016/j.jhydrol.2013.01.041

Barrios, A. G., \& Urribarri, L. A. (2010). Aplicación del modelo SWAT en Ios Andes venezolanos: cuenca alta del río Chama. Revista Geográfica Venezolana, 51(1), 11-29. Recovered from http://www.redalyc.org/pdf/3477/347730384002.pdf

Bautista-Ávalos, D., Cruz-Cárdenas, G., Moncayo-Estrada, R., Silva, J. T., \& Estrada-Godoy, F. (2014). Aplicación del modelo SWAT para evaluar la contaminación por fuentes difusas en la subcuenca del lago de Chapala, México. Revista Internacional de Contaminación Ambiental, 30(3), 263-274. Recovered from http://www.scielo.org.mx/pdf/rica/v30n3/v30n3a3.pdf

Bocco, G., Mendoza, M., \& Masera, O. R. (2001). La dinámica del cambio del uso del suelo en Michoacán: una propuesta metodológica para el estudio de los procesos de deforestación. Investigaciones Geográficas, 44, 18-36. Recovered from http://www.scielo.org.mx/pdf/igeo/n44/n44a3.pdf 
Tecnología y

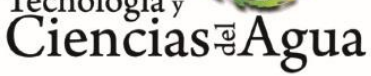

2022, Instituto Mexicano de Tecnología del Agua

Open Access bajo la licencia CC BY-NC-SA 4.0

(https://creativecommons.org/licenses/by-ncsa/4.0/)

Boyle, D. P., Gupta, H. V., \& Sorooshian, S. (2000). Toward improved calibration of hydrologic models: Combining the strengths of manual and automatic methods. Water Resources Research, 36(12), 36633674. DOI: $10.1029 / 2000$ WR900207

Bravo, E. M., Mendoza, M. E., \& Medina, O. L. E. (2009). Escenarios de erosión bajo diferentes manejos agrícolas en la cuenca del lago de Zirahuén, Michoacán, México. Investigaciones Geográficas, 68, 73-84. Recovered from http://revistas.unam.mx/index.php/rig/article/view/17999/17140

Brouziyne, Y., Abouabdillah, A., Bouabid, R., Benaabidate, L., \& Oueslati, O. (2017). SWAT manual calibration and parameters sensitivity analysis in a semi-arid watershed in North-western Morocco. Arabian Journal of Geosciences, 10(19), 427. DOI: 10.1007/s12517-017-32209

Castillejo-González, I. L., López-Granados, F., García-Ferrer, A., PeñaBarragán, J. M., Jurado-Expósito, M., De-la-Orden, M. S., \& GonzálezAudicana, M. (2009). Object-and pixel-based analysis for mapping crops and their agro-environmental associated measures using QuickBird imagery. Computers and Electronics in Agriculture, 68(2), 207-215. DOI: 10.1016/j.compag.2009.06.004

Choi, W. (2007). Estimating land-use change impacts on direct runoff and non-point source pollutant loads in the Richland Creek basin (Illinois, USA) by applying the L-THIA model. Journal Spatial Hydrology, 7(1), 47-65.

Recovered

from http://www.spatialhydrology.net/index.php/JOSH/article/view/64/63 
Tecnología y

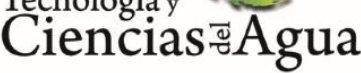

2022, Instituto Mexicano de Tecnología del Agua

Open Access bajo la licencia CC BY-NC-SA 4.0

(https://creativecommons.org/licenses/by-nc$\mathrm{sa} / 4.0 /)$

Chuvieco, E. (2002). Teledetección ambiental. Barcelona, España: Ariel.

Congalton, R. G. (1991). A review of assessing the accuracy of classifications of remotely sensed data. Remote Sensing of Environment, 37(1), 35-46. DOI: https:10.1016/00344257(91)90048-B

Cruz-Cárdenas, G., Ortiz-Solorio, C. A., Ojeda-Trejo, E., MartínezMontoya, J. F., Sotelo-Ruiz, E. D., \& Licona-Vargas, A. L. (2010). Evaluation of four digital classifiers for automated cartography of local soil classes based on reflectance and elevation in Mexico. International Journal of Remote Sensing, 31(3), 665-679. DOI: $10.1080 / 01431160902894491$

Cruz-Cárdenas, G., Silva, J. T., Ochoa-Estrada, S., Estrada-Godoy, F., \& Nava-Velázquez, J. (2017). Delineation of environmental units by multivariate techniques in the Duero River Watershed, Michoacán, Mexico. Environmental Modeling \& Assessment, 22(3), 257-266. DOI: $10.1007 / \mathrm{s} 1066$

Cuo, L. (2016). Land use/cover change impacts on hydrology in large river basins. Cover change impacts on hydrology in large river basins. In: Tang, Q., \& Oki, T. (eds.) Terrestrial Water cycle and climate change: Natural and human-induced impacts (103-134). Washington DC, USA: Wiley.

Defries, R. S., Rudel, T., Uriarte, M., \& Hansen, M. (2010). Deforestation driven by urban population growth and agricultural trade in the twentyfirst century. Nature Geoscience, 3(3), 178-181. DOI: 
2022, Instituto Mexicano de Tecnología del Agua

Tecnología y Open Access bajo la licencia CC BY-NC-SA 4.0 (https://creativecommons.org/licenses/by-nc$\mathrm{sa} / 4.0 /)$

\section{$10.1038 /$ ngeo 756}

Estrada-Godoy, F., Silva, J. T., Ochoa, S., Moncayo-Estrada, R., CruzCárdenas, G., Villalpando, F., Ramos, A., \& Nava, J. (2013). Aplicación del método SINTACS para la determinación de la vulnerabilidad acuífera en la cuenca del río Duero, Michoacán, México. Revista Internacional de Contaminación Ambiental, 29, 235-248. Recovered from http://www.scielo.org.mx/pdf/rica/v29n4/v29n4a2.pdf

FAO, Organización de las Naciones Unidas para la Agricultura y la Alimentación. (2001). El papel de la agricultura en el desarrollo de los países MA y su integración en la economía mundial. Roma, Italia: Oficina Regional para América Latina y el Caribe.

Foley, J. A., DeFries, R., Asner, G. P., Barford, C., Bonan, G., Carpenter, S. R., Chapin, F. S., Coe, T. M., Dauly, G. C., Gibbs, H. K., Helkowski, J. H., Holloway, T., Howard, E. A., Kucharik, C. J., Monfreda, C., Patz, J. A., Prentice, C., \& Ramankutty, P. K. (2005). Global consequences of land use. Science, 309(5734), 570-574. DOI: $10.1126 /$ science. 1111772

Fregoso, A., Velázquez, A., Bocco, G., \& Cortéz, G. (2001). El enfoque de paisaje en el manejo forestal de la comunidad indígena de Nuevo San Juan Parangaricutiro, Michoacán, México. Investigaciones Geográficas, 46, 58-77. Recovered from http://www.scielo.org.mx/pdf/igeo/n46/n46a6.pdf

Gauquelin, T., Michon, G., Joffre, R., Duponnois, R., Génin, D., Fady, B., Dagher, M. B., Derridj, A., Slimani, S., Badri, W., Alifriqui, M., Auclair, 
Tecnología y

Ciencias Agua
2022, Instituto Mexicano de Tecnología del Agua

Open Access bajo la licencia CC BY-NC-SA 4.0 (https://creativecommons.org/licenses/by-nc$\mathrm{sa} / 4.0 /$ )

L., Simenel, R., Aderghal, M., \& Baudoin, E. (2018). Mediterranean forests, land use and climate change: A social-ecological perspective. Regional Environmental Change, 18(3), 623-636. DOI: 10.1007/s1011 Gebremicael, T. G., Mohamed, Y. A., Betrie, G. D., Van-der-Zaag, P., \& Teferi, E. (2013). Trend analysis of runoff and sediment fluxes in the Upper Blue Nile basin: A combined analysis of statistical tests, physically based models and land use maps. Journal of Hydrology, 48, 57-68. DOI: $10.1016 / j . j$ hydrol.2012.12.023

Ha, L. T., Bastiaanssen, W. G., Griensven, A. V., Van Dijk, A. I., \& Senay, G. B. (2018). Calibration of spatially distributed hydrological processes and model parameters in SWAT using remote sensing data and an autocalibration procedure: A case study in a Vietnamese river basin. Water, 10(2), 212. DOI: $10.3390 / w 10020212$

Hernández, T. A. D., Scarpare, F. V., \& Seabra, J. E. A. (2018). Assessment of the recent land use change dynamics related to sugarcane expansion and the associated effects on water resources availability. Journal of Cleaner Production, 197, 1328-1341. DOI: 10.1016/j.jclepro.2018.06.297

Hundecha, Y., \& Bárdossy, A. (2004). Modeling of the effect of land use changes on the runoff generation of a river basin through parameter regionalization of a watershed model. Journal of Hydrology, 292(1), 281-295. DOI : 10.1016/j.jhydrol.2004.01.002

INEGI, Instituto Nacional de Estadística y Geografía. (2014). Continuo de elevaciones mexicano 3.0 (CEM 3.0). Aguascalientes, México. 
Tecnología y

Ciencias:Agua
2022, Instituto Mexicano de Tecnología del Agua

Open Access bajo la licencia CC BY-NC-SA 4.0

(https://creativecommons.org/licenses/by-nc$\mathrm{sa} / 4.0 /)$

Recovered

from

http://www.inegi.org.mx/geo/contenidos/datosrelieve/continental/des carga.aspx

INIFAP \& Conabio, Instituto Nacional de Investigaciones Forestales, Agrícolas y Pecuarias \& Comisión Nacional para el Conocimiento y Uso de la Biodiversidad. (1995). Edafología, Escalas 1:250000 y 1:1000000. México, DF, México: Instituto Nacional de Investigaciones Forestales, Agrícolas y Pecuarias, y Comisión Nacional para el Conocimiento y Uso de la Biodiversidad

IPCC, Intergovernmental Panel on Climate Change. (2014). Climate Change 2014-Impacts, Adaptation and Vulnerability: Regional Aspects. New York, USA: Cambridge University.

Jayakrishnan, R., Srinivasan, R., Santhi, C., \& Arnold, J. G. (2005). Advances in the application of the SWAT model for water resources management. Hydrological Processes, 19, 749-762. DOI: 10.1002/hyp. 5624

Jiménez-Valverde, A., Acevedo, P., Barbosa, A. M., Lobo, J. M., \& Real, R. (2013). Discrimination capacity in species distribution models depends on the representativeness of the environmental domain. Global Ecology and Biogeography, 22(4), 508-516. DOI: 10.1111/geb.12007

Kauffman, J. B., Hughes, R. F., \& Heider, C. (2009). Carbon pool and biomass dynamics associated with deforestation, land use, and agricultural abandonment in the neotropics. Ecological Applications, 19(5), 1211-1222. DOI:10.1890/08-1696.1. 
Tecnología y

Ciencias $\cong$ Agua
2022, Instituto Mexicano de Tecnología del Agua

Open Access bajo la licencia CC BY-NC-SA 4.0

(https://creativecommons.org/licenses/by-ncsa/4.0/)

Krause, P., Boyle, D. P., \& Bäse, F. (2005). Comparison of different efficiency criteria for hydrological model assessment. Advances in Geosciences, 5, 89-97. Recovered from https://hal.archivesouvertes.fr/hal-00296842/

Lo, C. P., \& Yeung, A. K. (2007). Concepts and techniques of geographic information systems. International Journal of Geographical Information Science, 17(8), 819-820. DOI: 10.1080/1365881031000111173

Ma, L., Ascough II, J. C., Ahuja, L. R., Shaffer, M. J., Hanson, J. D., \& Rojas, K. W. (2000). Root zone water quality model sensitivity analysis using Monte Carlo simulation. Transactions of the ASAE, 43(4), 883. DOI:10.13031/2013.2984.

Magaña, V. (2004). El cambio climático global: comprender el problema. En: Martínez, J., \& Fernández, B. A. (eds.) Cambio climático: una visión desde México (17-27). México, DF, México: Instituto Nacional de Ecología, Secretaría del Medio Ambiente y Recursos Naturales.

Mas-Caussel, J. F., Velásquez-Montes, A., Fernández-Vargas, T. (2005). Monitoreo de los cambios de cobertura del suelo en Michoacán. En: Villaseñor-Gómez, E. (ed.) La biodiversidad en Michoacán: estudio de estado (204-206). México, DF, México: Comisión Nacional para el Conocimiento y Uso de la Biodiversidad, Secretaría del Medio Ambiente y Recursos Naturales, Universidad Michoacana de San Nicolás de Hidalgo.

Mawdsley, J. R., O’Malley, R., \& Ojima, D. S. (2009). A review of climate change adaptation strategies for wildlife management and biodiversity 
2022, Instituto Mexicano de Tecnología del Agua

Tecnología y

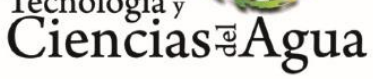

Open Access bajo la licencia CC BY-NC-SA 4.0 (https://creativecommons.org/licenses/by-nc$\mathrm{sa} / 4.0 /$ )

conservation. Conservation Biology, 23(5), 1080-1089. DOI: $10.1111 / \mathrm{j} .1523-1739.2009 .01264$

Meng, X. Y., Yu, D. L., \& Liu, Z. H. (2015). Energy balance-based SWAT model to simulate the mountain snowmelt and runoff-taking the application in Juntanghu watershed (China) as an example. Journal of Mountain Science,12(2), 368-381. DOI: 10.1007/s11629-014-3081-6

Nash, J. E., \& Sutcliffe, J. V. (1970). River flow forecasting through conceptual models part I-A discussion of principles. Journal of Hydrology, 10(3), 282-290. DOI: 10.1016/0022-1694(70)90255-6

NCEP, National Centers for Environmental Prediction. (2014). National Centers for Environmental Prediction. Maryland, USA: University Research Court College Park. Recovered from http://www.cpc.ncep.noaa.gov

Neitsch, L., Arnold, G., Kiniry, R., Srinivasan, R., \& Williams, R. (2010). Soil and water assessment tool. User's manual, version 2009, Technical Report No. 365. College Station, USA: Water Resources Institute.

Nie, W., Yuan, Y., Kepner, W., Nash, M. S., Jackson, M., \& Erickson, C. (2011). Assessing impacts of land use and landcover changes on hydrology for the upper San Pedro watershed. Journal of Hydrology, 407(1), 105-114. DOI: 10.1016/j.jhydrol.2011.07.012

Pineda-Jaimes, N. B., Bosque-Sendra, J., Gómez-Delgado, M., \& PlataRocha, W. (2009). Análisis de cambio del uso del suelo en el Estado de México mediante sistemas de información geográfica y técnicas de 
Tecnología y

Ciencias $\stackrel{\Xi}{\Im}$ Aua
2022, Instituto Mexicano de Tecnología del Agua

Open Access bajo la licencia CC BY-NC-SA 4.0

(https://creativecommons.org/licenses/by-nc$\mathrm{sa} / 4.0 /$ )

regresión multivariantes: una aproximación a los procesos de deforestación. Investigaciones Geográficas, 69, 33-52. Recovered from http://www.scielo.org.mx/pdf/igeo/n69/n69a4.pdf

Rasmussen, R., Ikeda, K., Liu, C., Gochis, D., Clark, M., Dai, A., Gutman, E., Dudhia, J., Chen, F., Barlage, M., \& Yates, D. (2014). Climate change impacts on the water balance of the Colorado headwaters: High-resolution regional climate model simulations. Journal of Hydrometeorology, 15(3), 1091-1116. DOI: 10.1175/JHM-D-130118.1

Semarnat, Secretaría de Medio Ambiente y Recursos Naturales. (2002). NOM-021-RECNAT-2000. Ciudad de México, México: Diario Oficial de la Federación.

Silva, G. J. T., \& Ramos, L. J. A. (1998). Elementos de vulnerabilidad de acuíferos para la protección de manantiales. Caso lago de Camécuaro. Michoacán, México. Memorias del Congreso Anual de la Unión Geofísica Mexicana. Puerto Vallarta, México.

Silva, J. T., Moncayo, R., Ochoa, S., Estrada, F., Cruz-Cárdenas, G., Escalera, C., Villalpando, F., Nava, J., Ramos, A., \& López, M. (2013). Calidad química del agua subterránea y superficial en la cuenca del río Duero, Michoacán. Tecnología y ciencias del agua, 4(5), 127-146. Recovered from http://www.scielo.org.mx/pdf/tca/v4n5/v4n5a9.pdf

Silva-García, J. T., Ochoa-Estrada, S., Cruz-Cárdenas, G., NavaVelázquez, J., \& Villalpando-Barragán, F. (2016). Manantiales de la cuenca del río Duero Michoacán: operación, calidad y cantidad. Revista 
Tecnología y

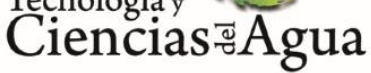

2022, Instituto Mexicano de Tecnología del Agua

Open Access bajo la licencia CC BY-NC-SA 4.0

(https://creativecommons.org/licenses/by-nc$\mathrm{sa} / 4.0 /)$

Internacional de Contaminación Ambiental, 32(1), 55-68. Recovered from

https://www.revistascca.unam.mx/rica/index.php/rica/article/view/50 $688 / 46550$

Smith, P., House, J. I., Bustamante, M., Sobocká, J., Harper, R., Pan, G., Wes, P. C., Clark, J. M., Adhya, T., Rumpel, C., Paustian, K., Kuikman, P., Francesca, M., Elliot, J. A., Mcdowell, R., Griffiths, R. I., Asakawa, S., Bondeau, A., Jain, A. K., Meersmans, J., \& Pugh, T. A. M. (2016). Global change pressures on soils from land use and management. Global Change Biology, 22(3), 1008-1028. DOI: 10.1111/gcb.13068

Soetaert, K., \& Herman, P. M. (2008). A practical guide to ecological modelling: Using $R$ as a simulation platform. Yerseke, The Netherlands: Springer.

Srinivasan, R., Zhang, X., \& Arnold, J. (2010). SWAT ungauged: Hydrological budget and crop yield predictions in the Upper Mississippi River Basin. Transactions of the ASABE, 53(5), 1533-1546. DOI: $10.13031 / 2013.34903$

Tölle, M. H., Engler, S., \& Panitz, H. J. (2017). Impact of abrupt land cover changes by tropical deforestation on Southeast Asian climate and agriculture. Journal of Climate, 30(7), 2587-2600. DOI: 10.1175/JCLID-16-0131.1

Torres-Benites, E., Fernández-Reynoso, D. S., Oropeza-Mota, J. L., \& Mejía-Saenz, E. (2004). Calibración del modelo hidrológico SWAT en la cuenca "El Tejocote", Atlacomulco, Estado de México. Terra 
Tecnología y

Ciencias $\approx$ Agua
2022, Instituto Mexicano de Tecnología del Agua Open Access bajo la licencia CC BY-NC-SA 4.0 (https://creativecommons.org/licenses/by-nc$\mathrm{sa} / 4.0 /$ )

Latinoamericana, 22(4), 437-444.

Valladares, F., Matesanz, S., Guilhaumon, F., Araújo, M. B., Balaguer, L., Benito, M., Cornwell, W., Gianoli, E., van-Kleunen, M., Naya, D. E., Nicotra, A. B., Pooter, H., \& Zavala, M. A. (2014). The effects of phenotypic plasticity and local adaptation on forecasts of species range shifts under climate change. Ecology Letters, 17(11), 1351-1364. DOI: 10.1111/ele. 12348

Xiong, L., Xu, X., Ren, D., Huang, Q., \& Huang, G. (2019). Enhancing the capability of hydrological models to simulate the regional agrohydrological processes in watersheds with shallow groundwater: Based on the SWAT framework. Journal of Hydrology, 572, 1-16. DOI:10.1016/j.jhydrol.2019.02.043

Zhou, F., Xu, Y., Chen, Y., Xu, C. Y., Gao, Y., \& Du, J. (2013). Hydrological response to urbanization at different spatio-temporal scales simulated by coupling of CLUE-S and the SWAT model in the Yangtze River Delta region. Journal of Hydrology, 485, 113-125. DOI: 10.1016/j.jhydrol.2012.12.040 